\title{
A felügyelt gépi tanulás kihívásai a szociológiai alkalmazásokban
}

\author{
NÉMETH RENÁTA ${ }^{1}$
}

\begin{abstract}
ABSZTRAKT
Az ipari/üzleti alkalmazásokban már sokszorosan bizonyított felügyelt gépi tanulás szociológiai alkalmazásai sajátos kérdéseket vetnek fel. A sajátosság oka, hogy ezekben az alkalmazásokban komplex fogalmak megtanulása az algoritmus feladata (pl. hogy gyúlöletbeszédet tartalmaz-e egy tweet). A felügyelt tanulás lényege, hogy elöre bekódolt (gyülöletbeszéd/nem gyülöletbeszéd) szövegek címkézését tanulja meg az algoritmus, jellegzetes szövegmintázatokat keresve. A felmerülő kérdések: hogyan jön létre a címkézés? Hogyan lehet betanított kódolókkal elvégeztetni egy olyan hermeneutikai kihívást, mint a gyúlöletbeszéd felismerése? Segítenek-e ezen a rutinszerüen alkalmazott, részletezett annotálási irányelvek? A cikk arra is kitér, hogyan végzik crowdsourcing platformokon a kódolást a nagy cégek, illetve ismertetem az MI-torzítást is, aminek itt az a lényege, hogy a kódolók maguk viszik be a diszkriminációt az adatokba. E kérdéseket kutatási tapasztalatainkkal illusztrálom.
\end{abstract}

KULCSSZAVAK: felügyelt gépi tanulás, annotálás, crowsourcing, MI-torzítás

\section{ABSTRACT}

\section{The challenges of supervised machine learning in sociological applications}

The sociological applications of supervised machine learning, already well proven in industrial/ business applications, raise specific questions. The reason for this specificity is that in these applications, the algorithm is tasked with learning complex concepts (e.g. whether a tweet contains hate speech). Supervised learning consists of learning to classify previously annotated (hate speech/non-hate speech) texts by the algorithm, looking for characteristic text patterns. The questions that arise are: how to prepare annotation? How can a hermeneutic challenge such as hate speech recognition be performed by annotators? Are routinely applied, detailed annotation guidelines helpful? The article also discusses how large companies perform coding on crowdsourcing platforms, and describes AI bias, which in this case means that annotators themselves introduce bias into the data. I illustrate these issues with our own research experiences.

KEYWORDS: supervised machine learning, annotation, crowsourcing, AI bias

${ }^{1}$ Eötvös Loránd Tudományegyetem, Társadalomtudományi Kar, Research Center for Computational Social Science, email:nemeth. renata@tatk.elte.hu. A szerzőt a K-134428 azonosítójú NKFIH pályázat támogatta kutatási munkájában. 


\section{TEMATIKUS TANULMÁNYOK - Digitális szociológia}

\section{Bevezetés}

A weboldalakon, közösségi média felületeken, szöveggé alakított videókon, digitalizált könyvtárakban felhalmozódott szövegek a társadalmi valóság sosem látott szélességű elérését teszik lehetővé. Individuális és kollektív cselekedeteinkről, szerepeinkről és csoportközi viszonyainkról, mindezek időbeli dinamikájáról és strukturális heterogenitásáról naponta többmillió terrabytenyi digitális szöveg keletkezik, s a meglevő adatvagyon néhány évente megsokszorozódik.

A digitális szövegeknek ez az univerzuma párhuzamosan olyan szöveganalitikai technológiákat hívott életre, melyek ennek az elérésnek ma már a szociológia számára is releváns mélységét nyújtják. Savage és Burrows 2007-ben az évtized egyik legtöbbet idézett szociológiai tanulmányában az empirikus szociológia közelgő válságáról írt. Azt jósolták, hogy válság következik be, ha a korábban saját módszertani szakértelméről ismert szociológia nem tud megfelelni a big data által támasztott kihívásoknak, és így elveszíti vezető szerepét. Ez nem következett be. Nyolc évvel később a British Sociological Association által kiadott „Sociological Futures” címü könyvsorozat első tagja (Ryan - McKie 2015) már a címében is utalt a válság végére, és fontos lehetőségeket látott a big data kutatásban, valamint az szövegbányászatban is. Ugyanakkor a korábban a szociológia által uralt empirikus szakértelmet tekintve egyértelmű elmozdulás figyelhető meg az akadémiai szférából az ipar felé, hiszen a terület hatalmas üzleti lehetőségeket generál és az ipar finanszírozni is képes a szükséges fejlesztéseket.

Ez a cikk a szövegbányászat egy alterületét mutatja be. A szövegbányászat izgalmas, és a szociológia számára is nagyon perspektivikus terület az informatika, mesterséges intelligencia-kutatás és nyelvészet határán. Utóbbi években tapasztalt felfutása mögött egyszerre áll a digitális szöveges források elérhetősége és a hatalmas adatbázisok feldolgozásához szükséges technológia fejlődése. Ambiciózus projektek használják üzleti alkalmazásokban, marketingben, kormányzati és védelmi területen egyaránt. Az elmúlt néhány évben a szövegbányászat a társadalomtudományokban is kezdett teret nyerni, az antropológiától a közgazdaságtanon át a szociológiáig². Természetesen, míg a szövegbányászat egy viszonylag új interdiszciplináris terület, maga a szövegelemzés több évtizedes tradícióra tekint vissza a társadalomkutatásban: kifinomult kvalitatív módszerek fejlődtek ki. A kvantitatív társadalomkutatási szövegelemzés inkább csak bizonyos kifejezések vagy kvalitatíve azonosított kódok megjelenését számszerűsítette a szövegekben, ehhez képest óriási előrelépést jelent a szövegbányászat eszköztára, ami olyan feladatok elvégzését teszi lehetővé, mint tematikus struktúrák vagy látens szemantikai relációk automatizált azonosítása (Németh - Katona - Kmetty 2020).

${ }^{2}$ Társadalomkutatóknak szóló kiváló összefoglaló a módszerről: Ignatow - Mihalcea 2017. 


\section{TEMATIKUS TANULMÁNYOK - Digitális szociológia}

Zárójelben megjegyezném, hogy a szövegbányászattal kapcsolatban sem az angol, sem a magyar terminológia nem kiforrott még, a természetesnyelv-feldolgozás (NLP, natural language processing), számítógépes nyelvészet, automatizált szövegelemzés diffúz körvonalakkal bíró, rokon, de nem szinonim elnevezések (Németh - Katona - Kmetty 2020).

Ebben a tanulmányban azokat a lehetőségeket tekintem át, amelyeket a felügyelt gépi tanulás nyújthat a szociológia számára. Ezeknek az ipari/üzleti alkalmazásokban már sokszorosan bizonyított algoritmusoknak a szociológiai alkalmazásai sajátos kérdéseket vetnek fel. A sajátosság oka, hogy ezekben az alkalmazásokban komplex fogalmak megtanulása az algoritmus feladata. A felügyelt tanulás lényege, hogy előre bekódolt szövegek címkézését tanulja meg az algoritmus, jellegzetes szövegmintázatokat keresve. A felmerülő kérdések: hogyan jön létre a címkézés? Hogyan lehet betanított kódolókkal elvégeztetni egy olyan hermeneutikai kihívást, mint a gyűlöletbeszéd felismerése? Segítenek-e ezen a rutinszerűen alkalmazott, részletezett annotálási irányelvek? Jobban végzi-e a kutató a besorolást, mint az egyszerű kódoló, vagyis magasabbrendű-e az egyik interpretáció, mint a másik? A cikk arra is kitér, hogyan végzik crowdsourcing platformokon a kódolást a nagy cégek, hogy müködik iparszerűen ez a humán/gép együttműködés, és milyen kérdések merülnek fel a crowsourcing interpretáció kapcsán. Végül röviden kitérek az AI-torzításra, aminek itt az a lényege, hogy a kódolók maguk viszik be a diszkriminációt az adatokba.

\section{Felügyelt vs. felügyelet nélküli gépi tanulás jellemzői}

Az alábbiakban röviden ismertetem a felügyelt és felügyelet nélküli tanulás logikáját, majd a felügyelt tanulás gyakorlati kivitelezését. Nem térek ki a módszer szöveganalitikai jellegzetességeire, arra, hogy mi a „szöveg”, mint input adat sajátossága a numerikus inputtal szemben, vagy hogy milyen módon keresnek a modellek mintázatokat a szövegekben. Utóbbi kérdések iránt érdeklődő olvasóknak a Németh Koltai (2021) szerzőpároshoz, illetve Németh, Katona és Kmetty (2020) szerzők szociológusokhoz szóló szövegbányászati bevezetőjét ajánlom.

A felügyelt és felügyelet nélküli tanulás mögött álló egzakt statisztikaelméletet Vapnik (2000) alaposan tárgyalja. Intuitíve, a felügyelt és felügyelet nélküli tanulás közötti különbség azon alapszik, hogy már létező elmélet/meglevő háttérismeret empirikus megnyilvánulásait keressük (felügyelt tanulás, ahol a „felügyelet” maga a háttérelmélet), vagy induktív módon egy még nem vizsgált téma feltárása a cél (felügyelet nélküli tanulás). A dichotómia hasonlít a klasszikus szociológia konfirmatív/ exploratív módszerek közötti különbségtételéhez.

A nem felügyelt módszerek némelyikét a klasszikus társadalomkutatásban is gyakran alkalmazzák, ilyen például a szövegekre alkalmazott klaszterelemzés. Ez olyan vektortérben definiálható, ahol a tengelyek a szavakat jelölik, a dokumentu- 


\section{TEMATIKUS TANULMÁNYOK - Digitális szociológia}

mok vektortérbeli helyét pedig az egyes szavak dokumentumbeli gyakorisága határozza meg. De nem felügyelt módszer a legújabb szövegbányászati megoldások alapját adó szóbeágyazás ${ }^{3}$ is. Ez a módszer az egyes szavakhoz rendel jelentést, még pedig un. disztribúciós szemantikai megközelítésben, amikoris a jelentést kizárólag a használati környezet határozza meg. A jelentésről tehát kizárólag címkézetlen adatokból tanul az algoritmus, nincs szükség kívülről bevitt szakértői tudásra. A disztribúciós szemantika használható a legkülönbözőbb területek hatalmas skáláján, így például a gépi fordításnál is.

Ezzel szemben a felügyelt tanulás lényege, hogy (elméletünk/háttérismeretünkre támaszkodva) előre bekódoljuk a szövegeket, majd ezeket a címkéket az algoritmus megpróbálja megtanulni. A kutató elméleti megfontolásai befolyásolják az elemzést, hiszen a címkék, mint kategóriák meghatározása megelőzi az elemzést. Egy társadalomkutatási példa Poletti és társai (2017) munkája, akik olasz nyelvű Twitter-üzeneteken igyekeztek automatikus gyülöletbeszéd-felismerőt létrehozni. A gyülöletbeszéd általuk alkalmazott definíció szerint valamely kisebbségi csoport ellen irányul és tartalmaz egyfajta illokúciós erőt, amely alkalmas a célcsoporttal szembeni erőszak terjesztésére, népszerűsítésére, alátámasztására vagy erre történő uszításra. Ezért a fogalom pontos megragadása érdekében a kódnak tartalmaznia kellett a célcsoportot (vallási, etnikai kisebbségek vagy migránsok), és a kódolók a tweetet olyan jegyekkel is felruházták, mint hogy sztereotipizál-e, tartalmaz-e agressziót, támadó-e, vagy tartalmaz-e az agressziót kendőzo iróniát.

A megtanulás itt azt jelenti, hogy (viszonylag alacsony hiba mellett) az algoritmus maga is képes lesz kódokat (gyűlöletbeszéd/nem gyúlöletbeszéd) rendelni még címkézetlen szövegekhez. A tanulási folyamat pedig a kutatók által címkézett két szöveghalmaz eltérését leginkább megfogó jellegzetes szövegmintázatok keresésén alapul, ahol az előre címkézett szövegek halmazát tanuló-halmaznak nevezzük. Nagyon leegyszerűsített példán: használhatunk logisztikus regressziót, ahol a függő változó a bináris címke (gyülöletbeszéd/nem gyülöletbeszéd), numerikus magyarázó változóink pedig azt jelölik, hogy az adott nyelv szavai hányszor fordulnak elő a szövegben; a cél a legjobban illeszkedő modellhez tartozó együtthatók megtalálása. A gyakorlatban persze ennél jóval komplexebb modelleket alkalmaznak, komplexebb (például stiláris jegyeket reprezentáló vagy a szöveg mélyebb szemantikai viszonyait megragadó) magyarázó változókkal, a nagy mennyiségű (több ezer) magyarázó változó miatt dimenziócsökkentő megoldásokkal és a túlillesztést elkerülni hivatott megoldásokkal, de az algoritmus létrejöttének logikája ott is hasonló.

A felügyelt osztályozás gyakran használt típusa a szentiment - vagy érzelemelemzés. Egy szöveg szentimentje a szerző attitűdje egy tárgyhoz (pozitív, negatív vagy semleges), míg az érzelmek a boldogságtól a haragig terjedő érzések. ${ }^{4} \mathrm{Ez}$ az

\footnotetext{
${ }^{3}$ Angolul word embedding, a módszerről lásd: Németh - Katona - Kmetty 2020.

${ }^{4}$ Összefoglaló az alkalmazott módszerekről: Nahili - Rezeg - Kazar 2020.
} 


\section{TEMATIKUS TANULMÁNYOK - Digitális szociológia}

alkalmazás mind üzleti, mind tudományos alkalmazásokban nagyon elterjedt. Szöveges adatok szentiment- vagy érzelem szerinti címkézésével vizsgálhatják például marketingesek, hogy hogyan reagálnak a felhasználók reklámokra, szolgáltatásokra vagy termékekre, digitális bölcsészek, hogy hogyan változnak a regényben megjelenített érzelmek, vagy szociológusok, hogy hogyan terjednek érzelmek és vélemények társadalmi hálózatokban.

A felügyelt módszerek abban támogatják tehát a kutatókat, hogy nagyobb szövegkorpuszt rövidebb idő alatt dolgozhassanak fel, mint amire az emberi kapacitás képes lenne. További (inkább tudományos elvárásokhoz igazodó) cél, hogy megértsük az automatikus címkézés mögött álló szabályokat, egyszerű példán: hogy lássuk, mely szóhasználat valószínűsíti leginkább a gyülöletbeszéd jelenlétét. Ez utóbbi cél tulajdonképpen azoknak a tartalmi-szociológiai interpretációra/magyarázatra lehetőséget adó jegyeknek a feltárását jelenti, amelyek az egyébként „fekete dobozként” múködő kódoló algoritmus mögött állnak ${ }^{5}$.

A felügyelt tanulásnak több új továbbfejlesztése létezik, ahol az eredeti logika kissé módosul. Így pl. az aktív tanulás esetén nem egy fix tanuló-halmazunk van, hanem az algoritmus maga kéri menet közben konkrét, még címkézetlen, de a tanulásban fontosnak tűnő szövegek címkézését, vagy a transzfer tanulás, amikor a címkézett adatoktól eltérő besorolási problémát kell a tanuló algoritmusnak megoldania (Eisenstein 2019).

A felügyelet nélküli módszerek a felügyelt technikákkal együtt is használatosak. Például a felügyelet nélküli módszerek hatékony alkalmazása, ahogy fentebb említettük, gyakran dimenziócsökkentést igényel, s ezek a dimenziócsökkentési eljárások gyakran felügyelet nélküliek. Így egy felügyelt tanulási regressziós modellben magyarázó változóként használhatjuk a klaszterelemzés által adott besorolást. De ugyanígy gyakori megoldás az, amikor felügyelt modellben a szöveget alkotó szavak helyett a szóbeágyazási modell által adott szójelentéseket használják magyarázó változóként.

\section{A felügyelt gépi tanulás inputja: humán annotálás}

Két karakteresen különböző megoldás létezik a tanuló-halmaz létrehozására. Az egyikre példa a fent már idézett, Poletti és társai (2017) által publikált kutatás: ők kódolókat (szövegbányászati terminussal: annotátorokat) tanítottak be részletes irányelvek alkalmazásával arra, mikor minősítsenek egy szöveget agresszívnek vagy támadónak, mikor sztereotipizál és mikor irányul egy kisebbségi csoport ellen a szö-

5 Erről a magyarázati igényről és általában a magyarázatra/predikcióra való törekvés kettőségéről lásd: Németh 2021: 110-121. 


\section{TEMATIKUS TANULMÁNYOK - Digitális szociológia}

veg. Itt tehát humán annotátorok vannak, akik olvasnak és interpretálnak, adott annotálási irányelveket követve.

A másik lehetőségre Jelveh, Kogut és Naidu (2014) írása példa, akik amerikai közgazdászok ideológiai pozíciójának (jobboldali/baloldali) gépi tanulását végezték el a szerzők tudományos írásai alapján. A tanuló-halmaz azokból a közgazdászoknak az írásaiból állt, akiknek pozíciója megállapítható volt politikai kampány-támogatásokat, illetve petíció aláírásokat tartalmazó nyilvántartások alapján. Itt tehát nincsenek humán annotátorok, nem olvasunk és nem interpretálunk, mert kész címkéink vannak.

A gyakorlatban leggyakrabban egy kutató (vagy egy kutatócsoport) kézzel végzi a kódolást, a szöveg annotálását, akárcsak a „klasszikus” kvalitatív szövegelemzés esetében. Az annotálás minőségének jelentősége kiemelkedő: a felügyelt tanuló algoritmus jó minőségben annotált tanuló-halmazból tud hatékonyan tanulni. Az annotálás persze időigényes és gyakran nem is egyszerű feladat. Az elsődleges cél a replikálhatóság, ami azt jelenti, hogy egy másik annotátor nagyon hasonló annotációkat készítene. Hovy és Lavid (2010) a következő strukturált eljárást javasolja az annotációk előállítására:

1. Határozzuk meg, hogy milyen kategóriákba sorolva kell annotálni. Ez általában valamilyen elmélet alapján történik (lásd: milyen jegyekkel definiálható a gyúlöletbeszéd). Itt megfelelő egyensúlyt kell találni a részletezettség/pontosság és a skálázhatóság/idővonzat között.

2. Választhatunk olyan platformot, amely támogatja az annotálás adminisztrálását. Több általános célú annotációs eszköz érhető el.

3. Az annotálási feladatra vonatkozó utasítások formalizálása annotálási irányelvek formájában. Amennyiben az utasítások nem explicitek, a kapott annotációk szubjektív benyomásokon alapulnak majd, ami a replikálhatóságot veszélyezteti.

4. Az adatok egy kis részhalmazának kísérleti annotálása (pilot), több annotátorral. A pilot előzetes benyomást ad mind a megismételhetőségről, mind az annotálási irányelvek alkalmazhatóságáról. A megismételhetőséget az annotátorok döntései közötti egyezés (inter-annotator agreement) mutatóival jellemezhetjük. A konkrét annotálási eltérések vizsgálata segíthet az utasítások pontosításában, és az annotálási feladat módosításához is vezethetnek.

5. Fő annotálás. Érdemes legalább az adatbázis egy részét párhuzamosan annotálni, azaz két vagy több annotátorral egymástól függetlenül besoroltatni, hogy az annotátorok közötti egyezés kiszámítható legyen. Sok projektben a szövegek több címkét is kapnak, amelyek aztán összesítve egy „konszenzusos” címkévé állnak öszsze. $^{6}$

${ }^{6}$ Példaként lásd: Danescu - Niculescu - Mizil et al. 2013. 


\section{TEMATIKUS TANULMÁNYOK - Digitális szociológia}

6. A felügyelt tanulás középpontjában az annotátorok közötti egyetértés áll: ha a kódok nem megbízhatóak, a tanuló algoritmus nem tud hatékonyan tanulni belőlük, és besorolásai sem lesznek megbízhatóak. Ezért elengedhetetlen az annotálás értékeléseként az annotátorok közötti egyezés mutatójának kiszámítása. Ha ez a mutató alacsony, az az annotátorok megbízhatóságát vagy magát a teljes annotációs rendszert (a besorolás értelmességét) kérdőjelezi meg. A mutató definíciójára több matematikai megoldás létezik a konkrét feladat függvényében. Az annotátorok besorolásainak egyszerű százalékos egyezése, annak ellenére, hogy nagyon széles körben használják, nem veszi figyelembe a véletlenszerűen előforduló egyezést. Ugyanis, ha két kommentátor véletlenszerűen választ két címke között, akkor a köztük lévő egyetértés várhatóan 50\%-os lesz. Ezért egy jó mutató a nyers egyezési százalékot a véletlen egyezés arányához viszonyítja. Egy ilyen széles körben használt mutató a Cohen-féle kappa is.

Érdemes megjegyeznünk, hogy ha az általunk vizsgált eset nem túl specifikus, nem feltétlenül kell saját annotálást végrehajtanunk, használhatunk mások által annotált adatbázisokat is. Számtalan annotált, nyílt elérésű korpusz található az interneten, melyek elsősorban nyelvészeti feladatokra alkalmazhatók, de találhatunk Twitter bot-detektálásra szolgáló címkézett adatbázisokat is, sőt társadalomkutatási célúakat is, mint a Manifesto projekt, amely ötven ország politikai pártjainak választási programjainak annotált adatbázisát nyújta 1945-től napjainkig.

\section{Egy saját kutatási példa}

Sik Domonkossal és Máté Fannival végzett kutatásunkban (Németh - Sik - Máté 2020) mi is a fentihez hasonló eljárást dolgoztunk ki. Kutatásunk célja az volt, hogy különböző felügyelt tanulói algoritmusok alkalmazásával automatikusan osztályozzuk ismert nemzetközi online depresszió-fórumok bejegyzéseit aszerint, hogy abban a depresszió milyen (bio-medikális, pszichológiai vagy társadalmi) keretezését adja a felhasználó.

Az annotátorokat a téma és a módszer iránt érdeklődő társadalomtudományi szakos hallgatók közül választottuk ki. A teljes adatbázisból, ami 70000 posztból állt, egyszerű véletlen mintavétellel 4500-at választottunk ki felcímkézendő tanulóhalmazként. Több tréninget tartottunk az annotátoroknak, és sok valós példát felvonultató, részletes annotálási irányelveket készítettünk, amelyet a pilot szakasz után is, és a fó annotálási szakaszban is folyamatosan frissítettünk. Öt címkét használtunk, mivel a három keretezés-típus mellé a „besorolhatatlan” (depresszióról van szó, de a keretezés nem azonosítható) és az „irreleváns” (nem depresszióról van szó) is hozzáadódott. Az annotálási feladat a legkevésbé sem volt triviális, ezért (1) az annotátorok szükség esetén két címkét rendelhettek a szövegekhez, egy elsődleges és egy (opcionális) másodlagos címkét. A bejegyzések 34\%-a kapott második címkét 


\section{TEMATIKUS TANULMÁNYOK - Digitális szociológia}

legalább az egyik annotátortól. Továbbá (2) minden szöveghez két független annotátorunk volt, akik együttesen legfeljebb négy címkét adtak. A végső, konszenzusos címke „többségi szavazáson” alapult, tehát a négy címke közül a leggyakoribbat választottuk. A (nagyon kevés, 12,3\%-os) kétértelmű esetek feloldására egy harmadik annotátort (egy vezető kutatót) kértünk fel. Másodlagos konszenzusos címkét is kiosztottunk, ha a „szavazásnak” volt egy egyértelmű második győztese.

Az annotátorok közötti egyezés mutatójának meghatározására a Cohen-féle kappát használtuk, amely azt mutatja meg, hogy az annotátorok mennyivel jobban teljesítenek a véletlenszerűen besoroló annotátorokhoz képest. Tökéletesen egyező besorolásoknál az értéke 1, ezzel szemben, ha az annotátorok véletlenszerűen választják ki a címkéket, akkor a kappa egyenlő 0-val.

Annotációnk másik sajátossága az volt, hogy az annotátorok másodlagos címkéket rendelhettek a bejegyzésekhez. Ha az egyezést az elsődleges címkék egyezéseként határozzuk meg, egyszerúen elvetve a választható másodlagos címkéket, akkor egy túlságosan konzervatív mérőszámot kapunk. Ezért a kappa „liberális” változatát használtuk, az egyezést úgy definiálva, hogy az egyik elsődleges címke megegyezik a másik annotátor által adott elsődleges vagy másodlagos címkével. A liberális kappa előnye az eredeti, konzervatív változatával szemben az, hogy figyelembe veszi a szövegek másodlagos jelentését is. Míg a liberális kappa túl optimista képet mutathat, addig konzervatív megfelelője túl szigorú értékeléshez vezet. Az „igazság” valahol a kettő között van, ezért mindkettőt bemutattuk. Konzervatív módon mérve az annotátoraink közötti egyezés 58,3\%, a liberális mérőszám pedig 69,7\% volt, ami elfogadható mértékű egyezést mutat.

\section{Crowdsourcing annotálás}

A tanulás sikerét közvetlenül befolyásolja a tanuló-halmaz mérete - hasonlóan ahhoz, ahogyan survey-ek esetén a mintanagyság a megbízhatóság megfontosabb faktora. Ezért nem ritkák a kifejezetten nagy (több tíz- vagy százezres) elemszámú annotálandó adatbázisok. Ezekben az esetekben a crowdsourcing platformokon bérelhető bedolgozó annotátorok jelentenek megoldást, például az Amazon által müködtetett Mechanical Turk, a Figure Eight, ${ }^{7}$ Lighttag vagy a kínai Weichaishi (1. ábra).

${ }^{7}$ Korábbi elnevezése CrowdFlower. 


\section{TEMATIKUS TANULMÁNYOK - Digitális szociológia}

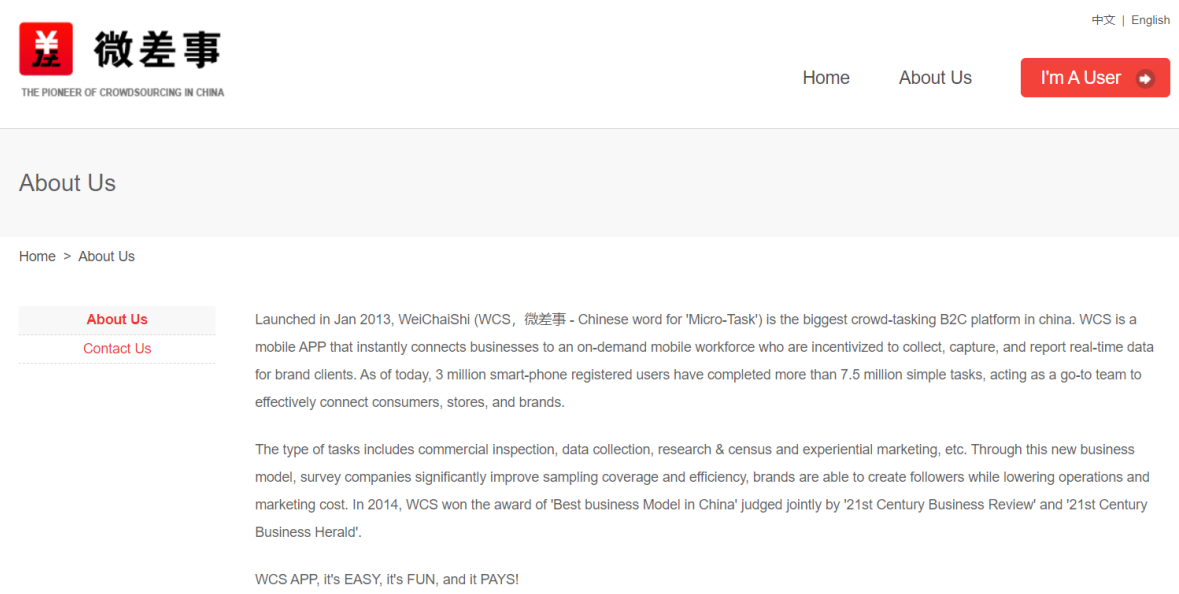

1. ábra. A WeiChaiShi kínai crowdsourcing cég beköszönő weboldala. A bedolgozók mobiltelefonján keresztüli adatgyüjtést, survey-eket és kísérleteket is kínálnak Forrás: http://www.weichaishi.com/

A crowdsourcing platformon annotáltatni kívánó kutatók egyszerūen felhívást tesznek közzé a platform bedolgozói között, melyben az annotáció darabbérén kívül az annotátorok elvárt képességeit (minimális képzettségét, anyanyelvét, korábbi munkáikkal kapcsolatos elégedettségi arányt stb.) adják meg (2. ábra). A viszonylag képzetlen „tömegmunkások” alkalmazása látszólag ellentétben áll a replikálhatóságra vonatkozó elvárásokkal, azonban számos, a platformot használó kutatás számol be megbízható annotációkról egyszerűbb feladatok kapcsán (Snow et al. 2008).

A crowdsourcing egy tágabb terület, az ember-alapú számítás (human-based computing, lásd még: elosztott gondolkodás, distributed thinking) részét képezi. Ez olyan számítástechnikai megoldásokat foglal magába, amelyekben egy számítógép úgy látja el a funkcióját, hogy bizonyos lépéseket embereknek szervez ki, egy szimbiózisszerű interakcióban (Mühlhoff 2019). Megfordulnak a szerepek: a gép kér fel embereket egy probléma megoldására, majd integrálja a megoldásokat. Az olyan számításigényes feladatok esetében, mint a képfelismerés, a humán annotáció fontos részét adja a mélytanuló algoritmusok tanításának.

A crowdsourcinggal kapcsolatban komoly etikai kérdések merülnek fel. Fort és Cohen (2011) már tíz éve arra figyelmeztetett, hogy az Amazon Mechanical Turk többszázezres bedolgozói tömeget működtet online, szerte a világban, jó részük él Indiában és Törökországban. A jellemző órabérek 2 dollár alatt vannak, és az általános elképzeléssel szemben a felhasználók jellemzően nem kismamák vagy diákok, aki hobbiként dolgoznak itt, hanem olyan munkavállalók, akik a megélhetéshez szükséges forrásként tekintenek munkájukra. Az alacsony béren kívül további ko- 


\section{TEMATIKUS TANULMÁNYOK - Digitális szociológia}

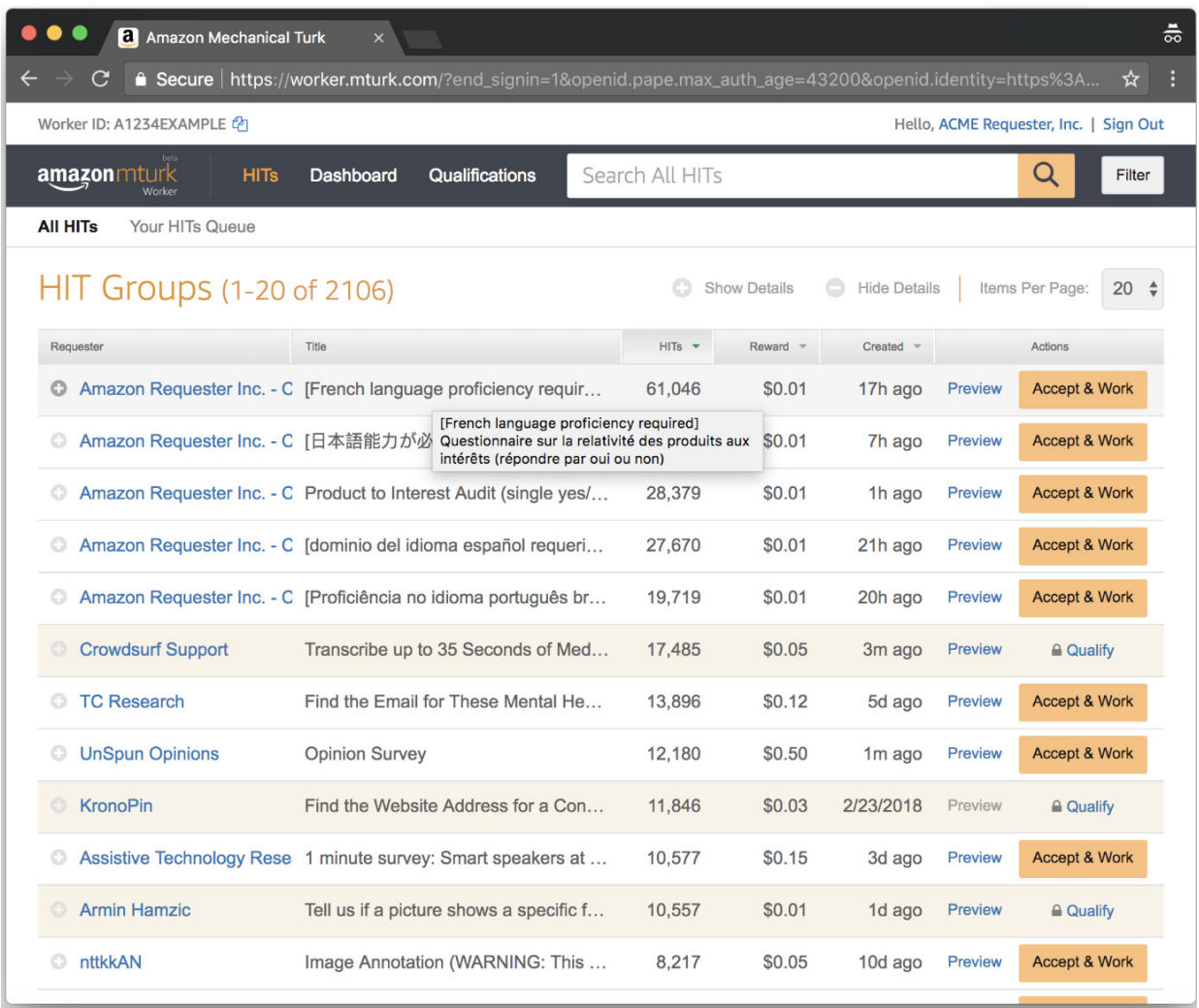

2. ábra. Az Amazon Mechanical Turk egy oldala a felkínált munkákkal, a munkaaadók (requesters) által fix darabbérért kínált un. HIT-ekre (Human Intelligence Tasks), elemi munkaegységekre osztott feladataival

Forrás: blog.mturk.com, https://blog.mturk.com/quick-update-another-improvement-to-the-mturk-worker-experience-9cfd0b1963e7

moly problémát jelent, hogy a munkavállalók (azaz „turkers”) híján vannak az olyan alapvető munkahelyi jogoknak, mint a kollektív alku, a szakszervezet alakításának lehetősége, a munkáltatói jogsérelmek orvoslásának lehetősége, ezért rendkívül kiszolgáltatottak.

Egy friss munka (Gray - Suri 2019) gazdaságantropológiai megközelítésben vizsgálja ezeknek a láthatatlanul dolgozó „szellemmunkásoknak” a körülményeit. A szerzők szerint az átláthatóság hiánya azt a benyomást kelti a közvéleményben, hogy a mesterséges intelligencia egyedül működteti a kortárs kényelmi szolgáltatásokat, miközben számos ponton elengedhetetlen az emberi beavatkozás: a szellemmunkások az annotáláson túl számos támogató munkát (személyazonosítás, feliratozás 


\section{TEMATIKUS TANULMÁNYOK - Digitális szociológia}

stb.) végeznek olyan óriások számára, mint az Amazon, a Google, az Uber és a Microsoft. A munkával járó anonimitás és rugalmasság kétségtelenül sokuknak előnyös, pl. az egyébként gyakran diszkriminált munkavállalói csoportoknak (nők, fogyatékkal élők). Ugyanakkor Fort és Cohen (2011) korábbi megfigyelései még mindig érvényesek, azzal a különbséggel, hogy ma már dolgozók millióira vonatkoznak: a szellemmunkások rendkívül alulfizetettek, kiszolgáltatottak, munkavállalói jogaik erősen sérülnek. A szerzők javaslatainak (munkavállalói juttatások bevezetése, szakszervezet alakítása, a munkavállaló és munkáltató közötti emberi kommunikációt lehetővé tevő új központok létrehozása) tétje nagy: a méltányos emberi munka jövőjét biztosítanák.

\section{A humán annotálás kihívásai szociológiai alkalmazásokban}

Az ipari/üzleti alkalmazásokban már sokszorosan bizonyított felügyelt gépi tanulás szociológiai alkalmazásai sajátos kérdéseket vetnek fel. A sajátosság oka, hogy ezekben az alkalmazásokban komplex fogalmak megtanulása az algoritmus feladata (lásd: gyülöletbeszédet tartalmaz-e egy tweet), szemben az olyan könnyebben annotálható feladattal, hogy negatív vagy pozitív-e egy szolgáltatással kapcsolatos bejegyzés.

Kutatásunk (Németh - Sik - Máté - 2020) már idézett esete jól példázza ezt: a depresszió keretezésének eldöntése nem bizonyult egyszerű feladatnak. A pilot során, az annotálási irányelvekben felsorolt elveken alapuló értelmezést több egyéni és csoportos fordulóban gyakorolták az annotátorok. Mégis, a pilot szakasz többszöri meghosszabbítása után is elégtelen maradt az annotátorok közötti egyetértés (az elsődleges címkék százalékos egyezése 60\% alatt volt). Ezen a ponton vált időszerűvé saját módszertani háttérfeltevéseink felülvizsgálata. Rá kellett jönnünk, hogy az általános kategóriák (keretezés típusok) és a konkrét hozzászólások ilyen jellegű társítása nem egyértelmű feladat. Gadamer hermeneutikai elméletét (2004) követve innét kezdve a jelentések kialakulását nyelvileg közvetített, interszubjektív, iteratív folyamatnak tekintettük, amelyben a jelentések ténylegesen egy folyamat során konstruálódnak. Módszertanilag ezt az interszubjektív folyamat az annotálási irányelvek folyamatos, iteratív frissítésében jelent meg. Ez a folyamat lényegesen különbözik azoktól a hermeneutikailag egyszerübb üzleti alkalmazásoktól, amelyek explicit és egyértelmű kategóriák (lásd pozitív/negatív/neutrális szentiment) előre meghatározott készletét alkalmazzák. A mi eljárásunk inkább egyfajta kvalitatív kódolásként határozható meg, mivel a kategóriáinkat egy előzetes absztrakt elméletből származtattuk, és induktív módon alakítottuk ki őket a kutatás során.

Az interszubjektivitás elismerésének másik megnyilvánulása a kettős annotációra való áttérés volt. Ahelyett, hogy azt feltételeztük volna, hogy minden egyes hozzászólás egy vagy két kategóriába tartozik, amelyeket egy megfelelően képzett 


\section{TEMATIKUS TANULMÁNYOK - Digitális szociológia}

annotátor azonosítani tud, úgy közelítettük meg a fórumbejegyzéseket, mint amelyek többféleképpen értelmezhetők. Annak érdekében, hogy minimalizáljuk az értelmezés esetlegességét, két független annotátorral kódoltattunk minden posztot. A végső, konszenzusos címke a két annotátor kódjának egyesítésén alapult a fent leírt módon.

Tapasztalataink szépen visszatükrözik más kutatók benyomásait. Aroyo és Welty (2015) egyenesen a humán annotálás hét mítoszaként utal azokra a naiv/pozitivista elképzelésekre, melyek egyértelműen kódolható szövegeket tételeznek fel. Szerintük a humán annotálás egy elavult szemantikai eszményen alapul, ami az egyetlen helyes igazság meglétét tételezi fel, ebből további mítoszokat levezetve, mint például az annotátorok közötti eltérés hátrányos voltát, azt a reményt, hogy a megfelelően részletezett annotálási irányelvek megoldják a problémát, annak hitét, hogy a szakértők besorolása mindig helyesebb, mint a laikusoké, vagy annak elvárását, hogy egyetlen kategóriába besorolható legyen a szöveg. Új szemantikai elméletet javasolnak, a „crowd truth”-ra alapozva, melynek lényege, hogy az emberi értelmezés szubjektív, és hogy az annotátorok különböző interpretációi jó reprezentációját adják ennek a szubjektivitásnak, s az ésszerű interpretációk tartományának.

\section{A Mesterséges Intelligencia torzítás és az annotálás}

A Mesterséges Intelligencia torzítás (MI-torzítás, angolul AI-bias, az Artificial Intelligence rövidítéseként) lényege, hogy a nyelvtechnológia outputja maga is társadalmi torzításokat (pl. kisebbségekkel, idősekkel vagy nőkkel szembeni hátrányos megkülönböztetést) mutat, amellyel mintegy felerősíti azok társadalmi hatását (Ntoutsi et al. 2020). Az egyik legismertebb példa az Amazon kísérleti rekrutációs algoritmusának esete (Dastin 2018). Az algoritmus létrehozásának célja az volt, hogy az 1-től 5-ig automatikusan osztályozza önéletrajzuk alapján a jelentkezőket. 2015-re azonban kiderült, az algoritmus gender-alapon torzított a szoftverfejlesztő és más technikai jellegú pozíciók esetén. Ennek oka az volt, hogy a modellt a céghez a megelőző 10 évben benyújtott jelentkezések alapján tanították, de a technológiai iparág férfi-dominált, így a jelentkezések is férfiaktól jöttek elsősorban. Emiatt az MI roszszabbul minősítette azokat a jelentkezéseket, amelyekben a „női” szó szerepelt, legyen az akár csak a „női sakkcsapat kapitány” kifejezés. A fejlesztők megkísérelték oly módon javítani, hogy az ilyen fajta nemi információtól való függést kiiktatták a tanulóból, de ez nyilván nem feltétlenül jelenti a probléma megoldását, hiszen egy ilyen rendszer más, nem vizsgált dimenziók mentén is tartalmazhat torzítást. A fejlesztők végül felhagytak ennek az algoritmusnak a használatával.

Az MI-torzítás általánosan megfogalmazva egyfajta anomália a gépi tanuló algoritmus outputjában; vagy az algoritmus fejlesztési folyamatában alkalmazott felte- 


\section{TEMATIKUS TANULMÁNYOK - Digitális szociológia}

vésekre vagy a tanuló-halmazban rejlő inherens társadalmi torzításokra vezethető vissza. Az annotálás kapcsán a továbbiakban az utóbbira koncentrálunk.

A tanuló halmaz, ember alkotta élő szöveg lévén mindazokat a viszonyokat tükrözi vissza, amik a társadalomban is megtalálhatók. Az Amazon példáján: a tanuló-halmaz kiegyensúlyozatlan volt nemi összetételét tekintve. Hasonló ismert példa a Google Translate esete is. Farkas Annával (Farkas - Németh 2022) végzett kutatásunkban azt vizsgáltuk, hogy ha magyarról angolra fordítunk foglalkozásneveket tartalmazó mondatokat („ő egy orvos”), akkor a fordító hímnemű vagy nőnemű névmást használ, s hogy ez a döntés korrelál-e a foglalkozások tényleges nemi megoszlásával illetve a magyarok survey-jel mért attitűdjével (azaz azzal, hogy inkább férfias vagy nőies foglalkozásnak vélnek valamit a magyarok). Eredményünk szerint a fordító erősen torzít a nőkkel szemben, és működése közelebb áll az attitűdökhöz, mint a tényleges foglalkozásszerkezethez (3. ábra).

\begin{tabular}{|c|c|c|c|c|c|c|c|c|c|c|c|c|}
\hline DETECT LANGUAGE & HUNGARIAN & ENGLISH & SPANISH & $\checkmark$ & & $\leftrightarrow$ & ENGLISH & SPANISH & ARABIC & $\checkmark$ & & \\
\hline \multicolumn{6}{|l|}{ ő egy orvos } & & \multicolumn{4}{|c|}{ he is a doctor } & & 绽 \\
\hline \multicolumn{7}{|c|}{ ő konferenciát szervez } & \multicolumn{6}{|c|}{ he is organizing a conference } \\
\hline \multicolumn{6}{|c|}{ ő erős } & & \multicolumn{6}{|c|}{ he is strong } \\
\hline \multicolumn{7}{|l|}{ ố egy bébiszitter } & \multicolumn{6}{|c|}{ she is a babysitter } \\
\hline \multicolumn{7}{|l|}{ ôfôz } & \multicolumn{6}{|c|}{ she cooks } \\
\hline \multicolumn{6}{|l|}{ ő szép } & & \multicolumn{6}{|c|}{ she is beautiful } \\
\hline$(4)$ & & & & $72 / 5000$ & 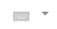 & & (1) & & & & $\square$ & $<$ \\
\hline
\end{tabular}

3. ábra. A Google Translate nemi torzítása

Forrás: Farkas - Németh 2022: 2

A fordító torzításának oka itt is az, hogy kétnyelvű szöveghalmazokon tanul, s ha a társadalmi attitűd vagy a tényleges foglalkozásszerkezet inkább férfiasnak mutat egy foglalkozást, akkor az a szövegekben is megmutatkozik majd, így a fordító is visszatükrözi ezt az egyenlőtlenséget. (A Google mai működésében már nem detektálható ez az anomália, a visszajelzések nyomán úgy módosították az algoritmust, hogy mindkét névmást megadja a fordítás.)

Az annotáción alapuló torzítás a tanuló-halmaz szintjén vihet anomáliát a rendszerbe, kétfajta úton. Vagy az annotátorok, maguk is társadalmi normákat képviselve, tükrözik vissza a címkézésben a társadalmi viszonyokat, vagy azzal okoznak torzítást, hogy nem reprezentálják kellőképpen a társadalom egészét. Mindkét probléma egyszerre volt jelen abban a gyülöletbeszéd-kutatásban (Sap et al. 2019), ahol a torzítást az okozta, hogy a jobbára fehér bőrű annotátorok a címkézendő tweetek szerzői által használt afroamerikai dialektust hajlamosabbak voltak offenzívként megjelölni. E dialektus ugyanis több káromkodást tartalmaz, és még ha az nem is irányul más felhasználók ellen, akkor is sértőnek, offenzívnek érezték a más nyelvi normákat képviselő kódolók. 


\section{TEMATIKUS TANULMÁNYOK - Digitális szociológia}

Eltávolítható-e a torzítás az algoritmusokból? Ahogy láttuk, az MI algoritmusok épp annyira lehetnek kiegyensúlyozottak bármilyen szempontból, mint amennyire a tanuló-halmaz az. „Reprezentatív” annotátor-csapat és „reprezentatív” tanuló minta kialakítására érdemes törekedni ugyan, de tökéletes reprezentativitás még elvileg is nehezen elképzelhető. Felmerül annak kérdése is, hogy valóban a nagy átlagot kell-e az algoritmusnak hoznia, nem lehet-e egy-egy kisebbségi csoport véleménye relevánsabb - gondoljunk itt akár egy tényellenőrzési feladatra, ahol a „tények” detektálása nem feltétlenül reprezentatív szavazással dönthető el.

Megkísérelhetjük továbbá nem az input, hanem az output oldalon is a javítást: a torzítás eltávolítását egy-egy dimenzió mentén (ahogy az Amazon fejlesztői tették), de számtalan látens dimenzió létezhet, ezért tökéletesen torzítatlan MI algoritmus nehezen elképzelhető - ugyanakkor törekedni kell tesztelésükre és javításukra.

\section{Összegzés}

A hatalmas mennyiségű digitális szöveges adat elérhetősége és új elemzési potenciálja széles perspektívát jelent a szociológia számára. A számítógépes társadalomtudomány, jelen példákon a szövegbányászat várhatóan akkor lesz beépíthető a mindennapi kutatásba, ha az interdiszciplináris együttműködések széles körben elterjednek, ha a szükséges tudás és kompetencia beépül az egyetemi képzésbe. A fejlett programozási ismereteket nem igénylő, alacsony küszöbű szövegelemző platformok ugyanakkor már most megjelentek (mint például a Google Trends, Google Ngram Viewer, vagy az európai fejlesztésű Sketch Engine), támogatva az átalakulást - ezek további fejlődése valószínűsíthető a közeljövőben.

Láttuk, hogy a szövegeken alapuló gépi tanulás is új lehetőségeket kínál a szociológia számára. A gépi tanulási megoldások egyre nagyobb része humán annotáción alapul, és az ilyen ember-gép együttműködésen alapuló számítások még erősebb felfutása várható nem csak az iparban, de a tudományban is. Az előre annotált és nyilvánosan elérhető adatbázisok már most támogatják a felügyelt tanulás saját alkalmazását. Ugyanakkor, mivel a szociológiai fogalmak általában komplexebbek, e humán annotáció során nem kerülhető meg az „igazság” egyértelműségének elvetése és az emberi értelmezés szubjektivitásának elfogadása.

A szociológus ugyanakkor nem csak felhasználóként, hanem a kritikai nézőpont képviselőjeként, a felügyelt gépi tanulás társadalmi hatásaira, etikai problémáira rámutató aktorként is jelen kell, hogy legyen. A crowdsourcing annotálás komoly munkaerőpiaci problémákat generál, az MI-torzítás pedig társadalmi hátrányokat erősíthet fel. Ezen túl a cikk keretein túlmutató, de zárásként mindenképp megemlítendő kérdés az internetes privacy és szabadság problémája. Kérdés, milyen hatása lesz ezekre a nagytömegű szövegek gyors feldolgozására képes technológia, nem válik-e a szövegbányászati technológia a cenzúra és megfigyelés mindenható eszközévé? 


\section{TEMATIKUS TANULMÁNYOK - Digitális szociológia}

\section{Irodalom}

Aroyo, L. - Welty, C. (2015): Truth is a lie: Crowd truth and the seven myths of human annotation. AI Magazine 36(1): 15-24. https://doi.org/10.1609/aimag. v36i1.2564

Dastin, J. (2018): Amazon scraps secret AI recruiting tool that showed bias against women. Reuters, https://www.reuters.com/article/us-amazon-com-jobsautomation-insight/amazon-scraps-secret-ai-recruiting-tool-that-showed-biasagainst-women-idUSKCN1MK08G (utolsó elérés: 2021. április 7.)

Eisenstein, J. (2019): Introduction to Natural Language Processing, MIT Press, Cambridge, MA

Farkas A. - Németh R. (2022): How to measure gender bias in machine translation: Real-world oriented machine translators, multiple reference points. Social Sciences \& Humanities Open, 5(1): 100239.

Fort, K. - Adda, G. - Cohen, K. B. (2011). Amazon mechanical turk: Gold mine or coal mine? Computational Linguistics 37(2):413-420. doi: 10.1162/COLI_a_00057

Gadamer, H. G. (2004): Truth and Method. 2. kiadás. Crossroad, New York

Gray, M. L. - Suri, S. (2019): Ghost Work: How to Stop Silicon Valley from Building a New Global Underclass. Houghton Mifflin Harcourt, Boston

Hovy, E. - Lavid J. (2010). Towards a 'science' of corpus annotation: a new methodological challenge for corpus linguistics. International Journal of Translation, 22(1): 13-36.

Ignatow ,G. - Mihalcea, R. F. (2017): An Introduction to Text Mining: Research Design, Data Collection, and Analysis (1st edition.). SAGE Publications, Inc., Los Angeles

Jelveh, Z. - Kogut, B. - Naidu, S. (2014): Detecting Latent Ideology in Expert Text: Evidence From Academic Papers in Economics. Proceedings of the 2014 Conference on Empirical Methods in Natural Language Processing (EMNLP) (pp. 1804-1809). Doha, Qatar: Association for Computational Linguistics. http:// www.aclweb.org/anthology/D14-1191. (utolsó elérés: 2021.11.20.)

Nahili, W. - Rezeg, K. - Kazar, O (2020): Big Data Analytics using Supervised Learning: A Comprehensive Review of Recent Techniques. International Journal for Research in Applied Science and Engineering Technology, 8(1): 305-312.

Mühlhoff, R. (2019): Human-aided artificial intelligence: Or, how to run large computations in human brains? Toward a media sociology of machine learning. New Media \& Society, 22(10): 1868-1884. https://doi. org/10.1177/1461444819885334

Németh R. - Koltai J. (2021): Sociological knowledge discovery through text analytics. In: Rudas T. - Péli G. (szerk.): Pathways between Social Science and Computational Social Science - Theories, Methods and Interpretations. Springer, New York 


\section{TEMATIKUS TANULMÁNYOK - Digitális szociológia}

Németh R. - Katona E. - Kmetty Z. (2020): Az automatizált szöveganalitika perspektívája a társadalomtudományokban. Szociológiai Szemle, 30(1):44-62.

Németh R. (2021): Az okság alternatív fogalmi és módszertani megközelítései a szociológiában. Savaria University Press, Szombathely

Németh R. - Sik D. - Máté F. (2020): Machine Learning of Concepts Hard Even for Humans: The Case of Online Depression Forums. International Journal of Qualitative Methods 19(1): 1-8. https://doi.org/10.1177/1609406920949338

Ntoutsi, E. et al. (2020): Bias in data-driven artificial intelligence systems - An introductory survey. Wiley Interdisciplinary Reviews Data Mining and Knowledge Discovery 10(6): 1-14. https://doi.org/10.1002/widm.1356

Poletto, F. - Stranisci, M. - Sanguinetti, M. - Patti, V. - Bosco, C. (2017): Hate Speech Annotation: Analysis of an Italian Twitter Corpus In: Basili, R. - Nissim, M. Satta, G. (eds.).: Proceedings of the Fourth Italian Conference on Computational Linguistics CLiC-it 2017: 11-12 December 2017, Rome. Accademia University Press, Torino https://doi.org/10.4000/books.aaccademia.2448.

Ryan, L. - McKie, L. (eds.) (2015). An end to the crisis of empirical sociology? Trends and challenges in social research. Routledge, London

Sap, M. - Card, D. - Gabriel, S. - Choi, Y. - Smith, N. A. (2019): The Risk of Racial Bias in Hate Speech Detection. In: Proceedings of the 57th Annual Meeting of the Association for Computational Linguistics, Association for Computational Linguistics, Florence, Italy.

Savage, M. - Burrows, R. (2007): The Coming Crisis of Empirical Sociology. Sociology: A Journal of the British Sociological Association, 41(5):885-899. https://doi. org/10.1177/0038038507080443

Snow, R. - O'Connor B. - Jurafsky D. - Ng A. Y. (2008): Cheap and fast-but is it good?: evaluating non-expert annotations for natural language tasks. In: Proceedings of the 2008 Conference on Empirical Methods in Natural Language Processing. Association for Computational Linguistics, Honolulu, Hawaii

Vapnik, V. N. (2000): The Nature of Statistical Learning Theory. 2. kiadás, SpringerVerlag, New York, Inc. 